\title{
Axial sampling height outperforms site as predictor of wood trait variation
}

\author{
Larissa C. Dória ${ }^{1 *}$, Diego S. Podadera ${ }^{2}$, Rivete S. Lima ${ }^{3}$, Frederic Lens ${ }^{1}$, \\ and Carmen R. Marcati ${ }^{4}$
}

${ }^{1}$ Naturalis Biodiversity Center, Leiden University, P.O. Box 9517, 2300 RA Leiden, The Netherlands.

${ }^{2}$ Programa de Pós-Graduação em Ecologia, UNICAMP, Campinas, São Paulo, Brazil.

${ }^{3}$ Universidade Federal da Paraíba, Centro de Ciências Exatas e da Natureza, Departamento de Sistemática e Ecologia, 58059-900, João Pessoa, Paraíba, Brazil.

${ }^{4}$ Universidade Estadual Paulista, UNESP, Faculdade de Ciências Agronômicas, Departamento de

Ciência Florestal, Avenida Universitária, no 3780, 18.610-034, Botucatu, SP, Brazil.

*Corresponding author; email: larissa.chacondoria@naturalis.nl

Accepted for publication: 12 March 2019

\begin{abstract}
Covariation amongst wood traits along the stem axis is important to maintain hydraulic integrity ensuring sufficient sap flow to the canopy. Here, we test how wood traits (co)vary along the trunk and whether two seasonally dry Brazilian habitats (cerrado and caatinga) influence this variation in two co-occurring species, Tocoyena formosa (Rubiaceae) and Tabebuia aurea (Bignoniaceae). The samples were collected at five heights along the main trunk of three individuals per species in both sites. We used light, scanning and transmission electron microscopy to observe the wood traits. Out of 13 wood traits, nine show relationships with sampling height: eight traits predict height in T. formosa and five in T. aurea. Contrastingly, only three traits show differences between sites and only for $T$. formosa. The intratrunk wood variation is reflected by the hydraulically weighted vessel diameter showing a curvilinear relationship, disagreeing with the prediction of a continuous vessel widening from tip to base. In both species, the largest vessels are linked to the thinnest intervessel pit membranes. Wood density increases basipetally for both species, being site-dependent and correlated with vessel traits in T. formosa, and site-independent and determined by fiber wall thickness in T. aurea. Furthermore, the functional role of rays was found to be different for each species, and may be related to the marked difference in ray composition. In conclusion, both species show a unique adaptation to deal with height-related constraints using species-specific co-variation amongst wood traits, while site does not contribute much to the wood variation.
\end{abstract}

Keywords: Caatinga, cerrado, intraspecific variation, thickness of intervessel pit membrane, Tocoyena formosa, Tabebuia aurea, vessel widening.

Note: Supplementary material can be accessed in the online edition of this journal via brill.com/iawa. 


\section{INTRODUCTION}

There is a vast wood anatomical literature describing an endless variation in anatomical characters between co-occurring species as well as species growing in contrasting environments, emphasizing the ability of plants to develop anatomical strategies to cope with similar or different environmental constraints (Carlquist 1975; Baas \& Schweingruber 1987; Hacke \& Sperry 2001; Lens et al. 2004; Pratt et al. 2007; Poorter et al. 2010; O'Brien et al. 2017). However, studies investigating functional covariation amongst xylem anatomical traits at the individual level remain scarce (Petit et al. 2010; Andofillo et al.2013; Olson et al.2018; Pfautsch et al.2018). According to the cohesion-tension theory, maintaining hydraulic integrity becomes more challenging for plants with increasing height due to the more negative pressure inside the water conducting cells of the upper parts of trees, which is required to draw water upwards against gravity in order to reach the leaves (McCulloh \& Sperry 2005; Pfautsch et al. 2011; Olson et al. 2018). Likewise, the increase in hydraulic resistance with stem length predicted by the Hagen-Poiseuille's law states that maximum tree height is limited by the conflicting requirements for water transport efficiency and water column safety (McDowell et al. 2002; Koch et al. 2004; Domec et al. 2008).

There are several xylem anatomical characters that are known to change with tree height. The best studied character is conduit widening from top to bottom, as stated by the West, Brown and Enquist model (WBE model, West et al. 1999), implying that the total resistance of water transport will not increase with longer vessel networks (Fan et al. 2009; Petit et al. 2010; Olson \& Rosell 2013; Rosell et al. 2017; Olson et al. 2018; Pfautsch et al. 2018). Also, vessel density will decrease from top to bottom as shown by anatomical studies and predicted by hydraulic models (Höltta et al. 2011). The intervessel pits constitute a major proportion, roughly half, of the hydraulic resistance of the xylem (Sperry et al.2006) and are a key feature explaining the variation in embolism resistance amongst tree species (Lens et al.2011; Li et al.2016; Dória et al. 2018). The few studies dealing with intraspecific variation at the pit level showed that pit aperture diameter decreased and torus-margo overlap increased significantly with increasing height in the conifers Sequoia sempervirens, Sequoiadendron giganteum, and Pseudotsuga menziesii (Burgess et al. 2006; Domec et al. 2008; Lazzarin et al. 2016), but variation in the ultrastructure of pits in the angiosperm Eucalyptus grandis was found to be more variable across vertical gradients (Pfautsch et al.2018).

In addition to conduits that impact hydraulic conductance, also stem mechanical characters - probably indirectly - impact the long-distance water transport in plants, suggesting the presence of a mechanical-functional trade-off. This relationship is often explained by the need to resist vessel collapse under drought-induced tension, either by vessel wall reinforcement (Hacke et al.2001; Fichot et al.2010) or by thick-walled fibers surrounding the vessels (Jacobsen et al. 2005, 2007; Chave et al. 2009; Pratt \& Jacobsen 2017) that theoretically lead to higher wood densities (Poorter et al. 2010; Zanne et al.2010). Likewise, also in herbaceous species, more lignified stems are linked with hydraulic safety in angiosperms (Lens et al. 2013,2016; Dória et al.2018; Dória et al. in press). 
Here, we investigate samples along the vertical axis of the trunk in two woody species (Tabebuia aurea, Bignoniaceae; Tocoyena formosa, Rubiaceae) that occur both in the distinctive cerrado and caatinga vegetation types experiencing seasonal drought. The cerrado is a savanna-like ecosystem located in the Brazilian Central Plateau, characterized by a strong seasonal climate with distinctive and regular wet and dry periods (Oliveira \& Marquis 2002), experiencing a mean annual precipitation of $1500 \mathrm{~mm}$ and a mean annual temperature of $22{ }^{\circ} \mathrm{C}$ (Silva et al. 2008). A remarkable characteristic of the cerrado is the deep and nutrient-poor soils with high aluminium content, which is toxic to most plants (Coutinho 2002). The caatinga is a tropical dry forest type located in the semiarid region of the northeast of Brazil, surrounded by the atlantic rainforest and the cerrado domains (Nimer 1972). The caatinga has a mean annual temperature of $27^{\circ} \mathrm{C}$ and a mean annual precipitation of less than $1000 \mathrm{~mm}$ (Andrade-Lima 1981; IBGE 2012), and is defined by a longer and more intense dry season compared to the cerrado (often over five months up to 11 months in some areas), and an irregular precipitation distribution over the years (Moro et al. 2016).

An earlier study on Tabebuia aurea and Tocoyena formosa showed specific wood anatomical strategies to cope with environmental differences between cerrado and caatinga (Dória et al. 2016). Here, we sampled individuals from the same population and focus on intraspecific wood trait variation along the vertical axis of the trunk of the same two species and environments (sites). Our study has two major objectives: (1) assess how wood traits vary along the vertical axis of the trunk in the two cooccurring species, and investigate to which extent differences between sites influence the variation in wood traits; (2) assess how wood traits covary amongst them and interpret this co-variation in a functional framework.

\section{MATERIALS AND METHODS}

\section{Sampling, species and field study}

We studied two woody deciduous species, Tabebuia aurea (Silva Manso) Benth. \& Hook.f. ex S.Moore and Tocoyena formosa (Cham. \& Schltdl.) K. Schum., both of common occurrence in both caatinga (Moro et al. 2014, 2016) and cerrado (Ratter et al . 2003). The two species have a distinctive wood anatomy, showing different anatomical strategies to deal with the environmental constraints of the two sites (Dória et al.2016). We selected three individuals from both species in each vegetation type, and collected wood samples from the outermost sapwood of the trunk at five different heights (I, at the base to $\mathrm{V}$, at the top of the trunk). Before sampling, we measured the total length of the trunk, collected sample $V$ at the highest point of the trunk, which was $30-50 \mathrm{~cm}$ below the branch endings, and subdivided the total trunk height by five in order to collect the remaining samples at equal distances along the main stem. In total, we collected 60 samples derived from the 12 individuals of the two species. The total tree height of the three T. aurea individuals varied from 6 to $8 \mathrm{~m}$ and 1.5 to $5 \mathrm{~m}$ for T. formosa.

The sampling site for both species in the cerrado was in Pratânia municipality, São Paulo state, Brazil ( $\left.22^{\circ} 48^{\prime} 35^{\prime \prime} \mathrm{S}, 48^{\circ} 39^{\prime} 57^{\prime \prime} \mathrm{W}\right)$. In the caatinga, the sampling was performed at two different sites, $20 \mathrm{~km}$ away from each other: for T. aurea in São João do Cariri municipality ( $7^{\circ} 23^{\prime} 27^{\prime \prime} \mathrm{S}, 36^{\circ} 32^{\prime} 2^{\prime \prime} \mathrm{W}$ ) and for T. formosa in Serra Branca 
municipality ( $\left.7^{\circ} 29^{\prime} 14^{\prime \prime} \mathrm{S}, 36^{\circ} 39^{\prime} 51^{\prime \prime} \mathrm{W}\right)$, both in the state of Paraíba, Brazil. In the cerrado sampling area, the mean temperature is below $25^{\circ} \mathrm{C}$, and the rainiest 5 -month period is from October to February with maximum monthly precipitation of $350 \mathrm{~mm}$. The 4-month dry season is from June to September when precipitation reaches less than 50 mm (data from Estação Experimental of the Faculdade de Ciências Agronômicas, UNESP, Botucatu Campus, Brazil). In the caatinga sampling areas, the mean annual temperature is higher (above $25^{\circ} \mathrm{C}$ ) and the dry season is longer ( 6 months from July to December) and more intense (precipitation reaching zero) compared to the cerrado. Also, during the irregular rainy season, the maximum monthly rainfall does not exceed 100 mm (data from Estação Experimental of São João do Cariri, Paraíba, Brazil).

\section{Sapwood density and wood anatomical features}

The list of the 13 wood traits assessed can be found in the Supplemental Table S1.

Wood density was determined for each of the 60 sapwood samples equalling about $1 \mathrm{~cm}^{3}$ in volume, as defined by the ratio of oven-dried mass (at $100{ }^{\circ} \mathrm{C}$ until constant weight of the sample) to fresh volume (by the weight of water displacement method) (Williamson \& Wiemann 2010).

Cross sections (15-20 $\mu \mathrm{m}$ thickness) for light microscopy (LM) were made using a sliding microtome in the Laboratório de Anatomia da Madeira, UNESP, Botucatu Campus, São Paulo State, for the total number of 60 samples for the two species. Sections were double stained with aqueous $1 \%$ safranin and aqueous $1 \%$ astra blue and mounted in synthetic resin (Entellan $\left.{ }^{\circledR}\right)$.

The wood anatomical measurements were performed for each of the 60 samples. The diameter of vessels $\left(\mathrm{D}_{\mathrm{V}}\right)$ was calculated based on the lumen area that was considered to be a circle according to the equation:

$$
\mathrm{D}_{\mathrm{V}}=\sqrt{\frac{4 A}{\pi}}
$$

where $\mathrm{D}_{\mathrm{V}}$ is the vessel diameter and $A$ is the vessel lumen area. The hydraulically weighted vessel diameter $\left(\mathrm{D}_{\mathrm{H}}\right)$ was calculated following the equation:

$$
\mathrm{D}_{\mathrm{H}}=\frac{\sum \mathrm{D}_{\mathrm{V}}{ }^{5}}{\sum \mathrm{D}_{\mathrm{V}} 4}
$$

where $\mathrm{D}_{\mathrm{V}}$ is the vessel diameter as measured in equation 1 .

For those samples from the top of the trunk (sampling height $\mathrm{V}$ ) that included pith we also measured the hydraulically weighted vessel diameter of the first formed secondary xylem vessels close to the pith as a proxy for the diameter of secondary xylem vessels closer to the stem apical meristem. This proxy is referred to as "sampling height VI".

In addition, we measured the vessel density $\left(\mathrm{V}_{\mathrm{D}}\right.$; number of vessel $\left./ \mathrm{mm}^{2}\right)$, vessel grouping index $\left(\mathrm{V}_{\mathrm{G}}\right)$ as proposed by Carlquist (2001) (number of vessels/number of vessel groups including solitary vessels as vessel groups of one) and the thickness of the vessel wall. Finally, theoretical hydraulic conductivity $\left(\mathrm{K}_{\mathrm{TH}}\right)$ was estimated for each sample using the following formula (Fichot et al.2010):

$$
\mathrm{K}_{\mathrm{TH}}=\frac{\mathrm{D}_{\mathrm{H}}^{4} \pi}{128 \eta} \times \mathrm{V}_{\mathrm{D}}
$$

where $\eta$ represents viscosity of water at $20^{\circ} \mathrm{C}\left(1.002 \times 10^{-9}, \mathrm{MPa} s\right), \mathrm{D}_{\mathrm{H}}$ represents the hydraulically weighted vessel diameter as calculated in Eq. 2 and $\mathrm{V}_{\mathrm{D}}$ the vessel density. 
For measuring the fractions of each of the xylem cell types (vessels, fibers, rays, and axial parenchyma), we used areas of $1 \mathrm{~mm}^{2}$ in cross-section images. We manually painted the area of each group of cell types in different colors using Adobe Photoshop CS6, and calculated the area occupied by each of these groups using Color Counter at ImageJ software (Schindelin et al. 2012).

For the ultrastructure of intervessel pits, one individual per site and per species (20 samples in total) was used for scanning electron microscopy (SEM) and transmission electron microscopy (TEM). For SEM, we stored the samples in ethanol $70 \%$, following the lab protocol of Dória et al. (2018), and observed the intervessel pits with a field emission SEM (Jeol JSM-7600F, Tokyo, Japan) at a voltage of $5 \mathrm{kV}$. For transmission electron microscopy (TEM) the samples were fixed for $48 \mathrm{~h}$ in Karnovsky fixative (Karnovsky 1965) and were subsequently treated according to the protocol described in Dória et al. (2018). The relaxed (non-aspirated) intervessel pit membranes were observed using a JEOL JEM 1400-Plus TEM (JEOL, Tokyo, Japan), equipped with a 11 MPixel camera (Quemesa, Olympus); at least 20 intervessel pit membranes per individual were measured.

All the SEM and TEM observations were carried out at the Naturalis Biodiversity Center, The Netherlands. For the stem-anatomical measurements, we followed the suggestions of the IAWA Committee (1989) and Scholz et al. (2013). The measurements were done using ImageJ (National Institutes of Health, Bethesda, USA).

\section{Data analysis}

To deal with differences in sampling height amongst individuals, we standardized the sampling height for each individual to scale in a range between 0 and 1 (min-max scaling).

Generalized mixed-effects models (GLMMs) were used to test the relationship between wood traits, the five sampling heights along the main stem, and the sites (caatinga and cerrado). Individuals were used as the random variable to account for the effect of different samples collected in the same individual. Likewise, GLMMs were used to test for relationships amongst wood traits. We calculated the $\mathrm{R}^{2}$ values based on the method of Nakagawa and Schielzeth (2013), using the function r-squared in the package piecewiseSEM (Lefcheck 2015).

All analyses were performed using R version 3.4.3 (R Core Team 2017) in R Studio version 1.1.414 (R Studio Team 2016) using the package nlme. All the differences were considered significant when $P<0.05$.

\section{RESULTS}

Regardless of site, the largest fraction of xylem tissues along the trunk in Tabebuia aurea is represented by fibers (varying from 0.51 to 0.53 ), followed by rays (varying from 0.19 to 0.24 ), axial parenchyma (varying from 0.15 to 0.18 ) and vessels (varying from 0.9 to 0.13 ) (Fig. 1). For Tocoyena formosa, the fiber fraction is the largest xylem tissue fraction (varying from 0.37 to 0.40 ), followed by ray fraction (varying from 0.29 to 0.37 ), vessel fraction (varying from 0.17 to 0.28 ) and axial parenchyma fraction (varying from 0.6 to 0.8 ) (Fig. 2). 


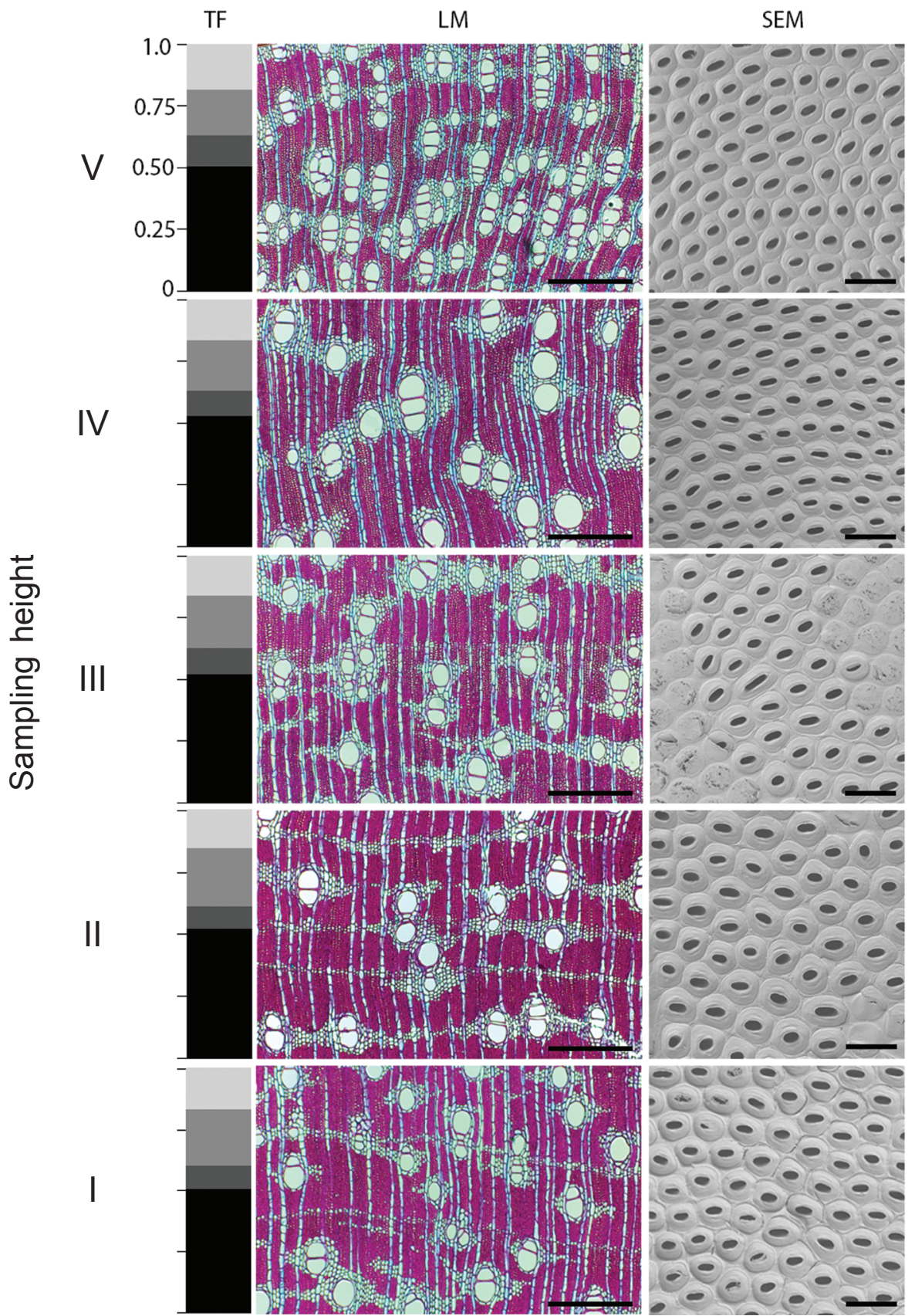

Figure 1. Tissue fractions (TF), light microscope cross sections (LM) and scanning electron microscope (SEM) surfaces of Tabebuia aurea along the five sampling heights (I: at the basis of the trunk, V: at the top of the trunk). axial parenchyma fraction; — ray fraction; $\square$ vessel fraction; fiber fraction. - Scale bars $=500 \mu \mathrm{m}(\mathrm{LM}), 10 \mu \mathrm{m}$ (SEM). 


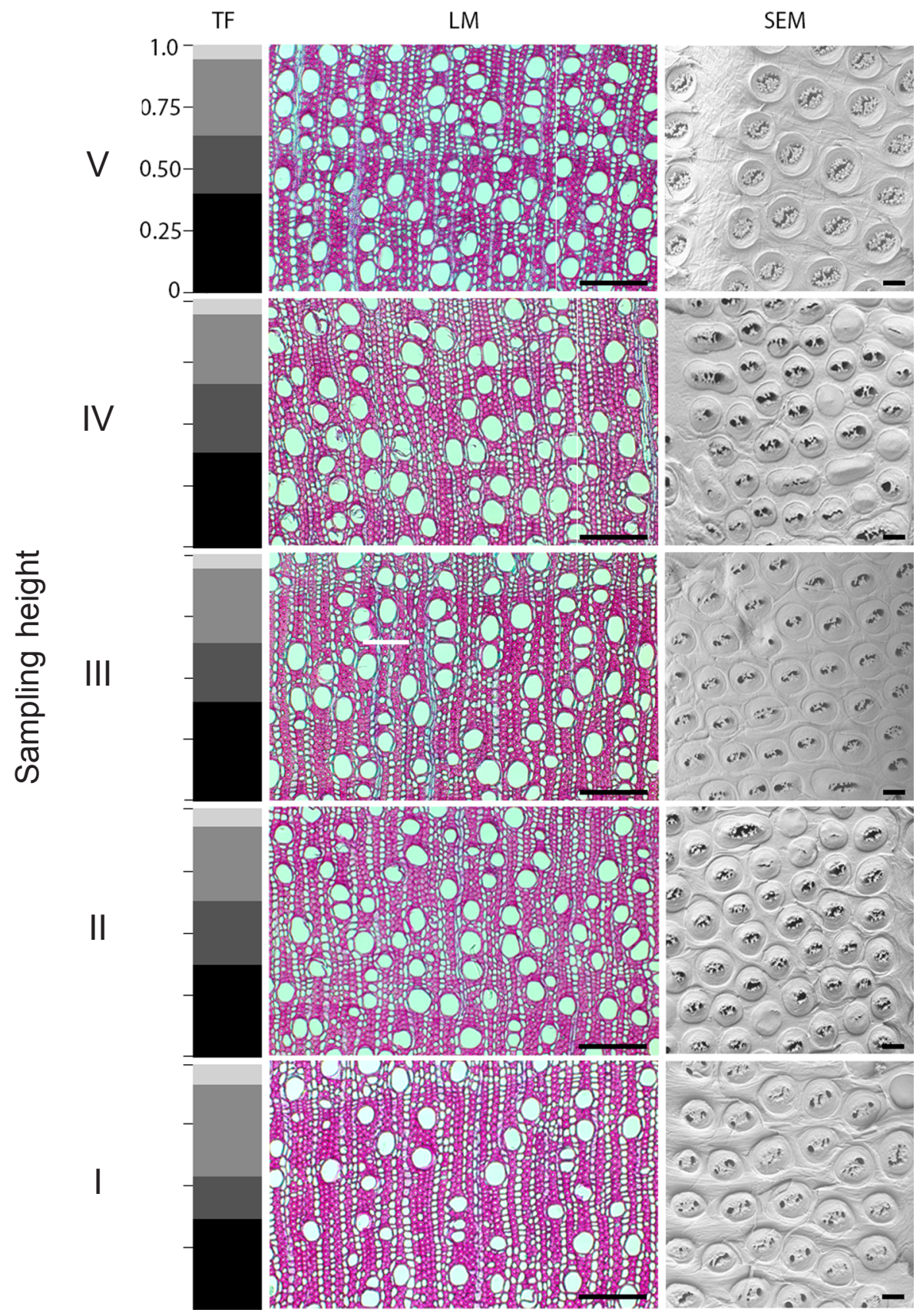

Figure 2. Tissue fractions (TF), light microscope cross sections (LM) and scanning electron microscope (SEM) surfaces of Tocoyena formosa along the five sampling heights (I: at the basis of the trunk, V: at the top of the trunk). axial parenchyma fraction; ray fraction; vessel fraction; fiber fraction. - Scale bars $=200 \mu \mathrm{m}(\mathrm{LM}), 2 \mu \mathrm{m}(\mathrm{SEM})$. 
There is no difference in pit and aperture size along the different sampling heights (Fig. 1 and 2). Likewise, there is no difference in ray morphology from top to bottom in both species, but at the same sampling height there is always a narrow zone of firstformed secondary xylem where the rays are composed of more upright ray cells.
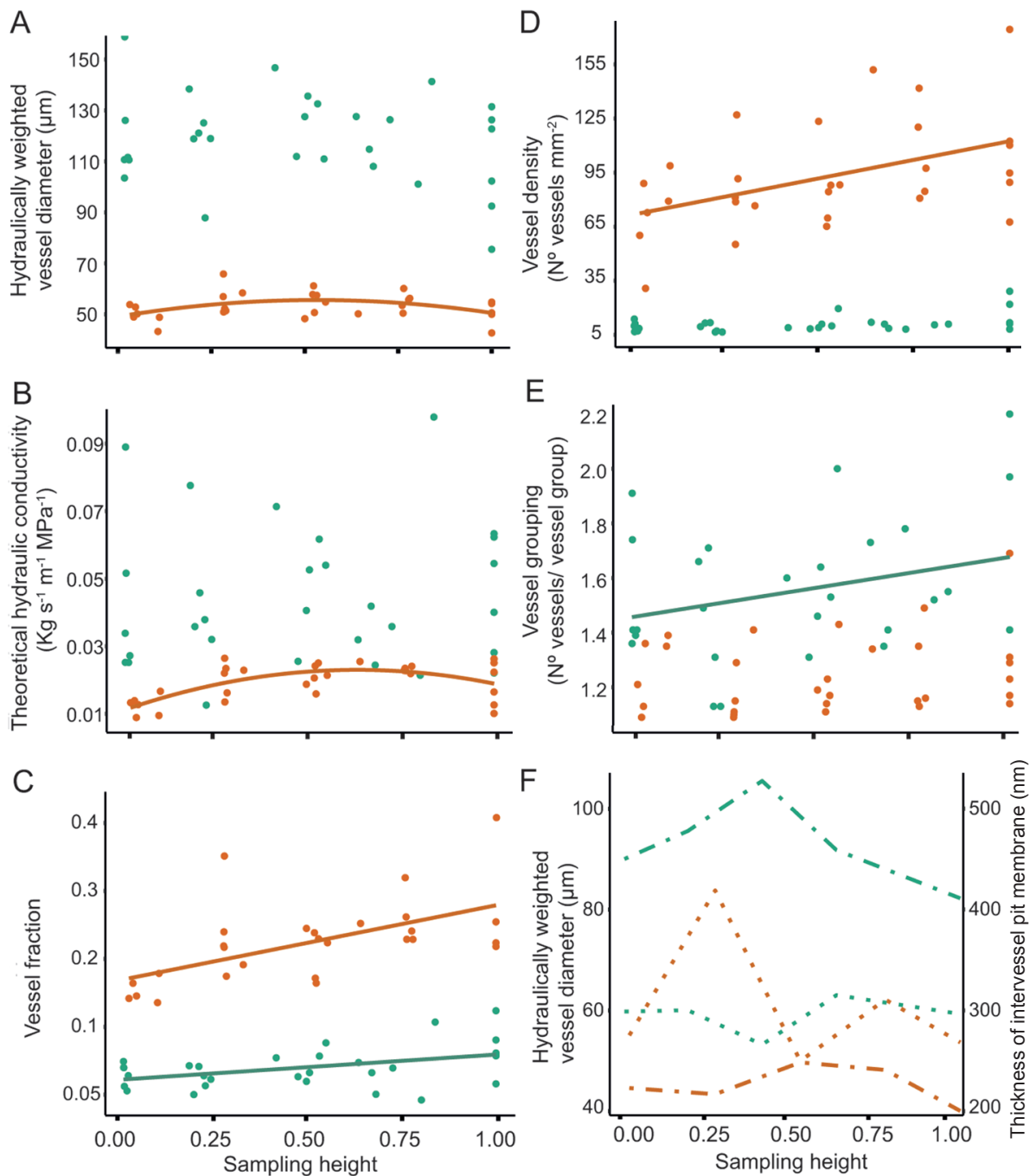

(Fig. 3 continued) $\rightarrow$

Figure 3. Relationships between wood traits and sampling height along the main trunk for individuals of Tabebuia aurea (green) and Tocoyena formosa (orange) occurring in caatinga and cerrado. The linear regression is shown for significant relationships $(P<0.05)$. Site dependent correlations, when present, are shown by filled squares (cerrado) and empty squares (caatinga). Sampling height $0.00-1.00$ refers to sampling height I-V.3F: $\cdot-\cdot-\cdot-$ hydraulically weighted vessel diameter;... thickness of intervessel pit membrane. 

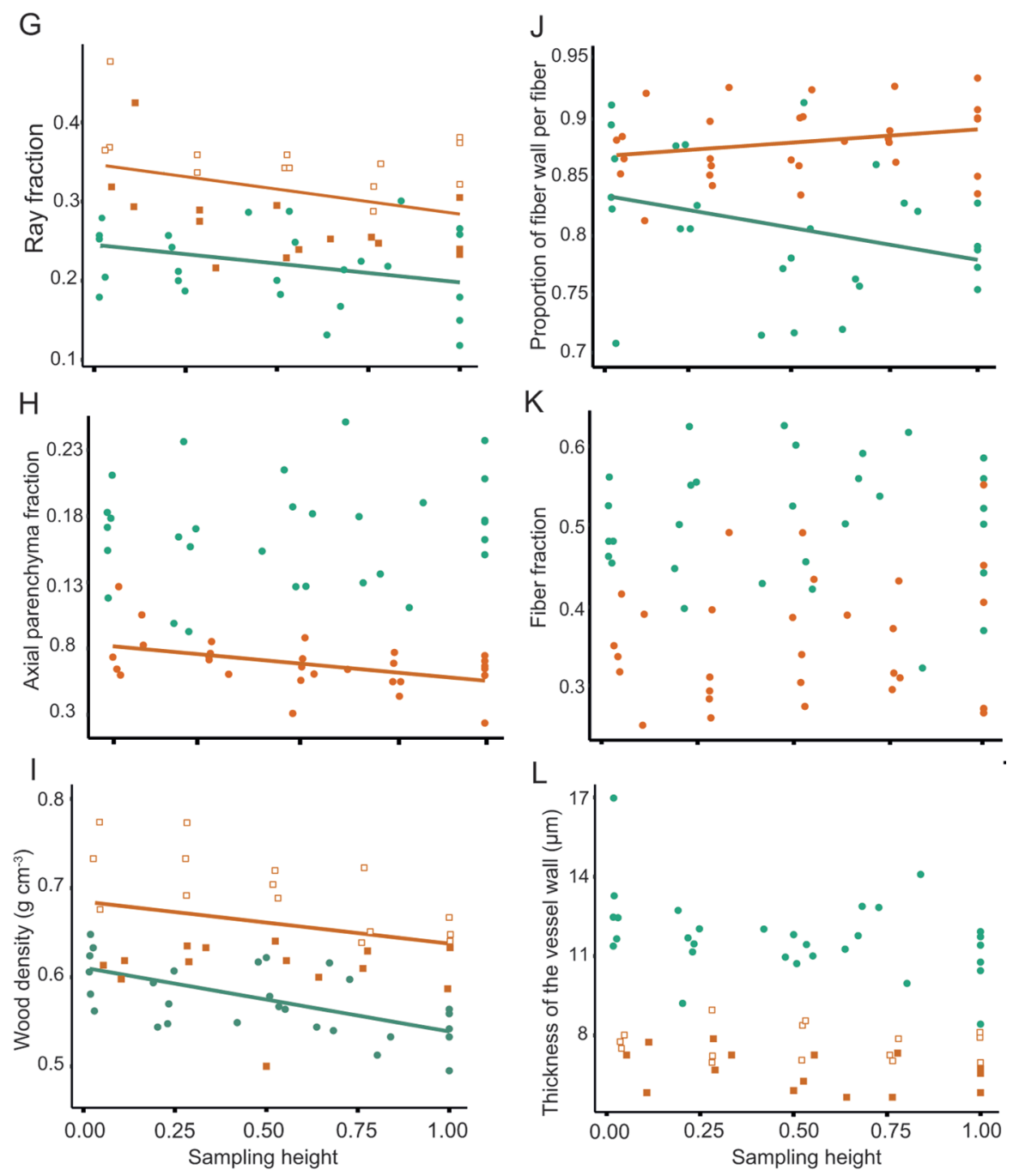

\section{Relationships between wood traits, sampling height and sites}

Out of 13 wood traits assessed, nine show relationships with the vertical axis and only three show differences between sites (Fig. 3).

The hydraulically weighted vessel diameter shows a similar curvilinear pattern with sampling height for Tabebuia aurea and Tocoyena formosa. For the former species, there is no significant relationship, but the latter species does show a significant curvilinear relationship with respect to hydraulically weighted vessel diameter (Fig. 3A; Suppl. Table S1) and theoretical hydraulic conductivity (Fig. 3B; Suppl. Table S1). Adding the measurements of secondary xylem vessels closer to the pith in sample height $\mathrm{V}$ as a proxy for vessels closer to the stem apical meristem ("sampling height VI"), we 


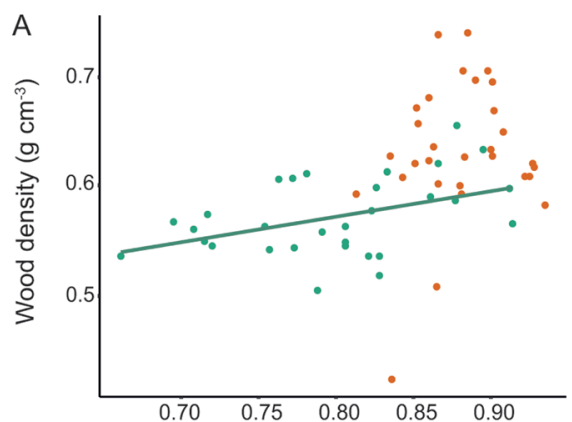

Proportion of fiber wall per fiber
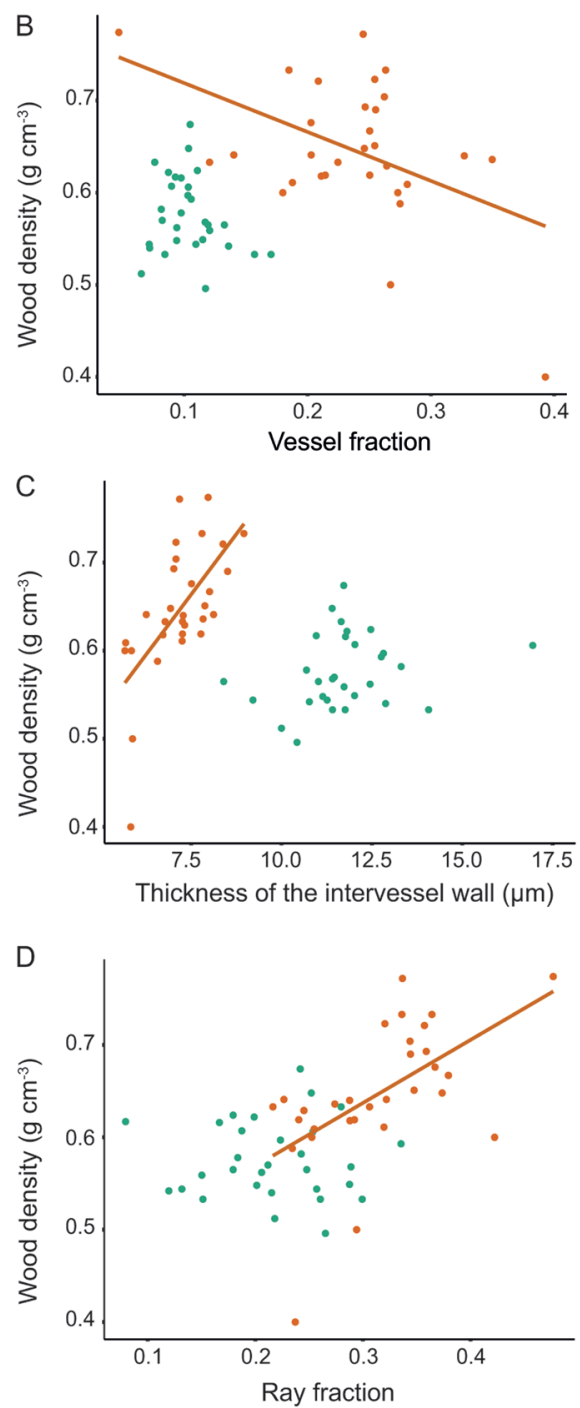
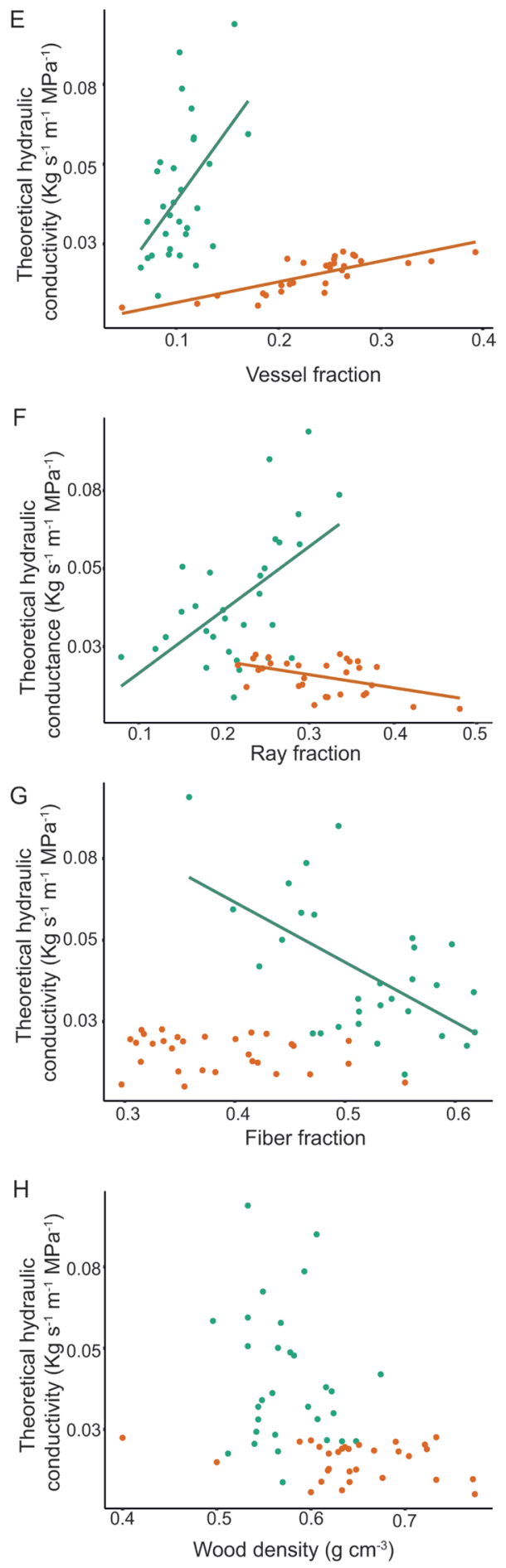
do find significant relationship for the two species (Suppl. Fig. S1; Suppl. Table S2). Vessel fraction is positively correlated with sampling height for both species (Fig. 3C; Suppl. Table S1; see also Fig. 1 and 2). Increasing vessel density with increasing sampling height is observed for T. formosa (Fig. 3D; Suppl. Table S1; see also Fig. 2), while increasing vessel grouping with increasing height is observed for T. aurea (Fig. 3E; Suppl. Table S1; see also Fig. 1).

The thickness of intervessel pit membranes varies considerably along the vertical trunk axis in both species, but independently from sampling height (Fig. 3F; Suppl. Table S1). For both species, the largest vessels have the thinnest pit membranes (Fig. 3F).

Ray fraction shows negative relationship for both species (Fig. 3G; Suppl. Table S1; see also Fig. 1 and 2), and it is higher in individuals of $T$. formosa from the caatinga than in those of the cerrado $(P=0.012$; Fig. $3 \mathrm{G})$. Likewise, axial parenchyma fraction also shows negative relationship with sampling height, but only for $T$. formosa (Fig. 3H; Suppl. Table S1; see also Fig. 2). Sampling height trends for both species are also observed for wood density (Fig. 3 I; Suppl. Table S1) which declines with increasing sampling height, and it is higher in individuals of $T$. formosa from the caatinga $(P=0.008$; Fig. 3I).

For the proportion of fiber wall per fiber, opposite linear trends are observed for each species (Fig. 3J; Suppl. Table S1): negative for T. aurea and positive for T. formosa. Fiber fraction and thickness of the intervessel wall are not predicted by sampling height for both species (Fig. 3K, L), though the latter shows differences between sites for $T$. formosa, with thicker intervessel walls in the individuals from caatinga $(P=0.043$; Fig. 3L).

\section{Relationships amongst wood traits}

Wood density varies less than 1.5-fold for Tabebuia aurea (from $0.50 \mathrm{~g} \mathrm{~cm}^{-3}$ to $0.67 \mathrm{~g} \mathrm{~cm}^{-3}$ ) and two-fold for Tocoyena formosa (from $0.40 \mathrm{~g} \mathrm{~cm}^{-3}$ to $0.77 \mathrm{~g} \mathrm{~cm}^{-3}$ ) for the 30 samples per species (Fig. 3 I). The variation of wood density in T. aurea is positively correlated with the variation of the proportion of fiber wall per fiber (Fig. 4A; $P<0.01, R^{2}=0.43$ ). On the other hand, in $T$. formosa it is negatively correlated with vessel fraction (Fig. 4B; $P=0.03, R^{2}=0.60$ ), and positively with thickness of the intervessel wall (Fig. 4C; $P=0.03, R^{2}=0.46$ ) and ray fraction (Fig. 4D; $\left.P=0.04, R^{2}=0.54\right)$.

As expected, theoretical hydraulic conductivity $\left(\mathrm{K}_{\mathrm{TH}}\right)$ is positively correlated with vessel fraction for both species (Fig. 4E; $P=0.03, R^{2}=0.51$ for $T$. aurea, and $P<0.001$, $R^{2}=0.74$ for $T$. formosa). $\mathrm{K}_{\mathrm{TH}}$ is also correlated with ray fraction (Fig. $4 \mathrm{~F}$ ), but shows opposite trends for each species: slightly positive for T. aurea $\left(P=0.05, R^{2}=0.42\right)$

Figure 4. Relationships amongst wood density, theoretical hydraulic conductivity and wood anatomical traits for individuals of Tabebuia aurea (green) and Tocoyena formosa (orange) occurring in caatinga and cerrado. The linear regression is shown for significant relationships $(P<0.05)$. No site correlations are detected. 
and negative for $T$. formosa $\left(P<0.001, R^{2}=0.74\right)$. Additionally, $\mathrm{K}_{\mathrm{TH}}$ is negatively correlated with fiber fraction for T. aurea (Fig. 4G; $P<0.013, R^{2}=0.51$ ). There is no relationship between $\mathrm{K}_{\mathrm{TH}}$ and wood density for either $T$. aurea or $T$. formosa $(P=0.57$; $P=0.24$, respectively, Fig. $4 \mathrm{H})$.
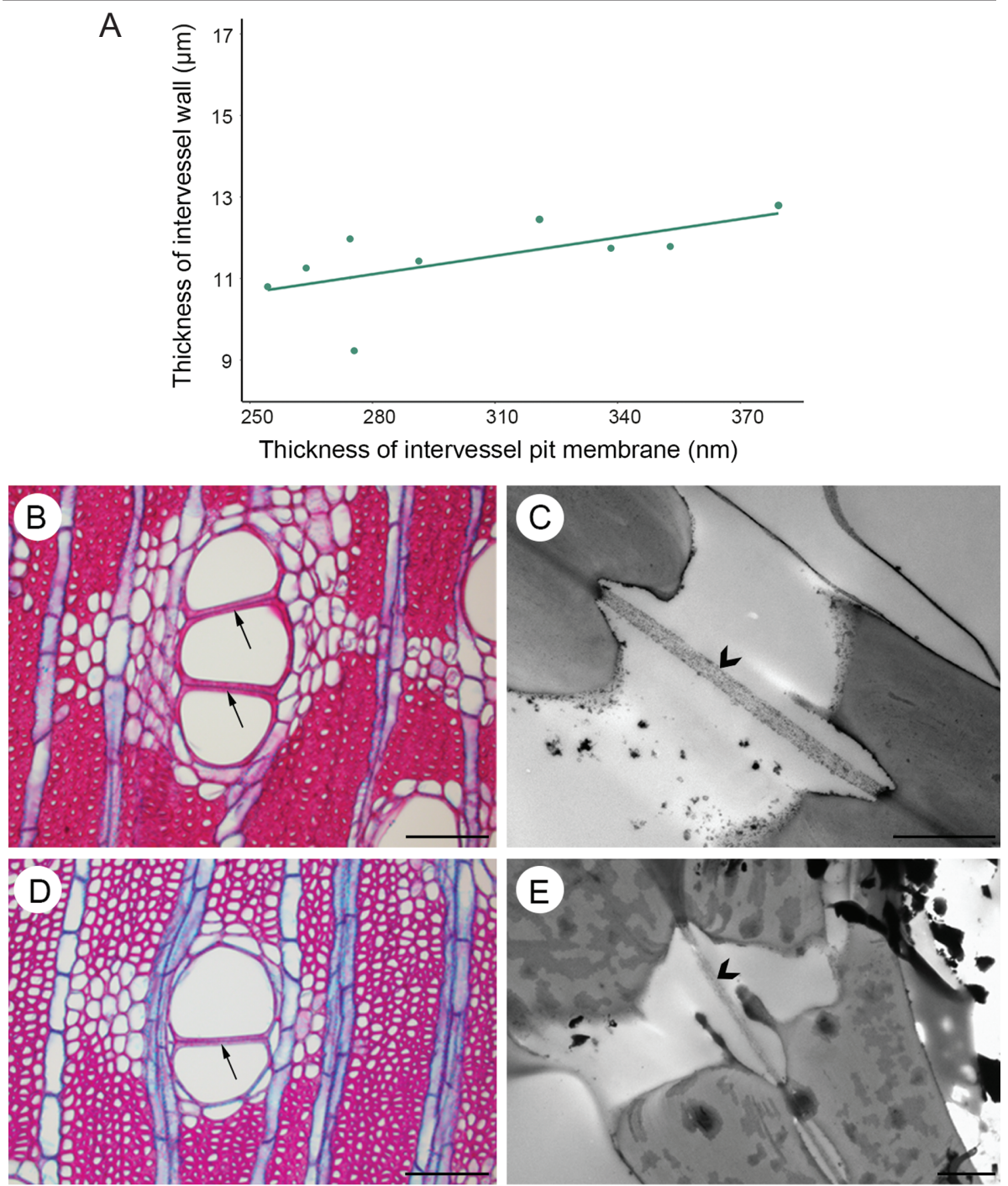

Figure 5. Relationships between the thickness of intervessel pit membrane $\left(\mathrm{T}_{\mathrm{PM}}\right)$ and vessel wall thickness in Tabebuia aurea. - A: Slightly positive relationship between $\mathrm{T}_{\mathrm{PM}}$ and the thickness of intervessel wall. - B \& D: Light microscopy cross sections showing vessel walls (arrows). - C \& E: Transmission electron microscopy illustrating intervessel pit membranes. The thickness of intervessel walls (arrows) matching with the thickness of the pit membrane (arrowheads). - Scale bars $=100 \mu \mathrm{m}(\mathrm{B}, \mathrm{D}) ; 2 \mu \mathrm{m}$ (C, E). 
Thickness of intervessel pit membrane $\left(\mathrm{T}_{\mathrm{PM}}\right)$ shows relationships with a different lignification character in the two species: a slightly positive relationship with the thickness of the vessel wall for T. aurea (Fig. 5A-E; $P=0.05, R^{2}=0.38$ ), and a negative relationship with the proportion of fiber wall per fiber for T. formosa (Fig. 6A-E; $\left.P=0.01, R^{2}=0.57\right)$.
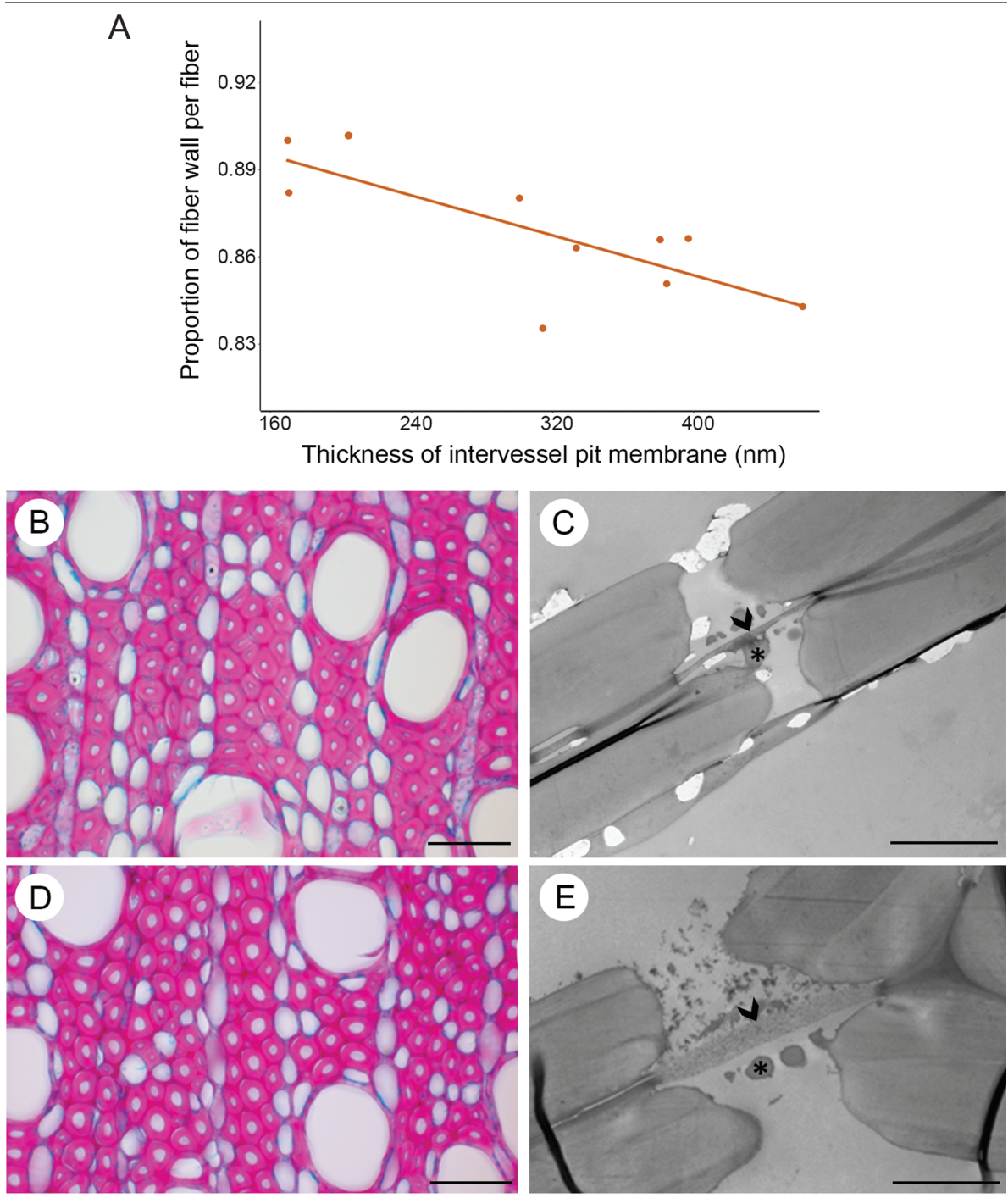

Figure 6. Relationships between the thickness of intervessel pit membrane $\left(\mathrm{T}_{\mathrm{PM}}\right)$ and fiber wall thickness in Tocoyena formosa. - A: Negative relationship between $\mathrm{T}_{\mathrm{PM}}$ and the proportion of the fiber wall per fiber. - B \& D: Light microscopy cross sections showing xylem fiber walls. - C \& E: Transmission electron microscopy illustrating intervessel pit membranes. The thickness of xylem fiber walls matching with the thickness of the pit membrane (arrowheads). Asterisks $(*)$ represent vestures. - Scale bars $=50 \mu \mathrm{m}(\mathrm{B}, \mathrm{D}) ; 2 \mu \mathrm{m}(\mathrm{C}, \mathrm{E})$. 


\section{DISCUSSION}

Our results show that there is considerable anatomical variation along the vertical gradient of individual trunks, which is functionally adapted to meet mechanical and hydraulic height-related constraints, but intraspecific variation between individuals inhabiting the different sites is negligible. This may seem surprising given the clear difference in rain seasonality (less and irregular distribution of rain throughout the years in caatinga $v s$. more and well-defined periods of rain in cerrado) and especially the marked difference in soil characteristics (deep and nutrient-poor soils with high aluminium content in cerrado). Furthermore, we have demonstrated that the two species occurring in both sites differ markedly in their wood anatomy and show specific adaptations to deal with the specific abiotic variables of the two sites (Dória et al. 2016).

\section{Relationships between wood traits and sampling height}

Although a continuous widening of vessel diameter from top to bottom is widely accepted as predicted by the WBE model (West et al. 1999; Rosell et al. 2017), our data show a narrowing of vessels at the base of the trunk for both species (Fig. 3A). A similar hump-shaped trend has also been reported in other trees such as Cordia alliodora and Anacardium excelsum (James et al. 2003) and in Eucalyptus grandis (Petit et al. 2010; Pfautsch et al.2018), and thereby disagreeing with the continuous vessel widening pattern from tip to base. The functional significance of vessel narrowing at the lowest portion of the stem remains debatable, however (Pfautsch et al. 2018). In our study, sampling height predicts hydraulically weighted vessel diameter in Tocoyena formosa only (Fig. 3A). However, this relationship becomes significant for both species when including the measurements of the secondary xylem vessels closer to pith region in sampling height $\mathrm{V}$ as a proxy for the vessel diameter closer to the stem apical meristem (referring to "sampling height VI"; Suppl. Fig. S1). Additionally, our results corroborate the prediction of a large dataset testing the relationship between basal and tip vessel diameters and stem length, showing that taller plants (Tabebuia aurea in our study) have wider conduits at both the base and the tip (Fig. 3A; Suppl. Fig. S1) (Olson et al. 2018). Since theoretical hydraulic conductivity $\left(\mathrm{K}_{\mathrm{TH}}\right)$ is estimated from the vessel diameter, the relationship between $\mathrm{K}_{\mathrm{TH}}$ and sampling height shows the same non-curvilinear pattern.

Vessel fraction shows the same vertical pattern in both species with increasing plant height (Fig. 3C). For the two species, the increase in vessel fraction towards the tip of the trunk is due to the effect of vessel density which also increases with plant height, though only slightly for T. aurea (Fig. 3D). This increase in number of vessels with height is a pattern supported by hydraulic optimal models along with vessel narrowing towards the apex (Höltta et al. 2011). In addition, the axial increase in vessel density and fraction compensates for the potential decrease in conductance due to the reduced vessel diameter (Carlquist 2001; Sperry et al. 2008). According to Aloni and Zimmermann (1983) and Aloni (2015), the increasing auxin concentration along the vertical axis of plants regulate cell differentiation and cell expansion rates, leading to more and narrower vessels closer to the stem apex.

While there is an increase of vessel grouping towards the upper parts of the trees in T. aurea, the same trend does not occur for T. formosa (Fig. 3E). Grouping of vessels 
can be functionally explained as a way of providing an alternate pathway for water transport within the same vessel multiple when water transport in some of the vessels is disabled by air embolism (Carlquist 1984). This strategy should minimize the number of water-filled vessels that are disconnected from the bulk sap stream, leading to a more efficient water transport mechanism in T. aurea (Mrad et al.2018; Jacobsen $\&$ Pratt 2018). The wood of T. formosa, on the other hand, has vascular tracheids at the end of growth rings (Dória et al. 2016), which can form a subsidiary conductive system in case too many of the mainly solitary vessels are embolized due to drought stress (Carlquist 1984, 2001; Spicer 2016).

For both species, the largest vessels are linked to the thinnest intervessel pit membranes (Fig. 3F). In terms of vessel development, it is expected that larger vessels would have thinner pit membranes than narrower vessels due to the stretching of the cell wall expansion during the vessel maturation stage (Hacke et al. 2017). Also from a hydraulic point of view, it makes sense that more efficient, wider (and presumably also longer) vessels towards the trunk base of taller trees have thinner intervessel pit membranes in order to synergistically reduce the resistance to long distance water transport (Hacke et al. 2006; Choat et al. 2008; Rosell et al. 2017). However, in a $20 \mathrm{~m}$ tall Eucalyptus grandis tree, Pfautsch et al. (2018) has provided clear evidence that wider vessels have the thickest intervessel pit membranes, which may act as protection from droughtinduced air bubble spread in the wider and presumably more vulnerable vessels.

Ray fraction decreases with increasing sampling height for the two species (Fig. $3 \mathrm{G}$ ), and the same pattern is observed for the fraction of axial parenchyma in $T$. formosa (Fig. 3H). This reduction of wood parenchyma in smaller sized stems may be a result of a lesser need of both sugar/water storage and radial transport. In addition, the diffuse-in-aggregates parenchyma pattern in T.formosa and the confluent parenchyma pattern in T. aurea are interconnected with rays and form an effective 3D parenchyma network (Carlquist 2001) that is more pronounced at the base of the trunk, which increases hydraulic capacitance via symplastic transport (Van Bell 1990; Holbrook 1995; Borchert \& Pockman 2005; Pfautsch et al. 2015).

Our results also show an increase in wood density with decreasing height for both species (Fig. 3 I), a pattern already shown in other studies (Kord et al.2010; Mattos et al. 2011). The main explanation for higher wood density in the lower part of the trunk is related to mechanics: for instance in T. aurea the proportion of fiber wall per fiber explains the higher wood density at the base of the trunk, which serves as mechanical reinforcement as a result of the increased weight that impacts this part of the plant. This phenomenon is probably also related to the observation that wood density tends to increase with cambium age (Zobel \& Sprague 1998), leading to denser wood at the lower parts of the trunk and lighter wood in the upper stem portions (Iqbal 1995; Zobel \& Sprague 1998; Moya et al. 2003).

Variation in wood density is linked with the proportion of fiber wall per fiber in T. aurea, but with vessel traits and ray fraction in T. formosa

Surprisingly, the variation in wood density for the two species studied is correlated with different characters. In Tabebuia aurea, the axial variation in wood density is posi- 
tively linked with the proportion of fiber wall per fiber (PFWF) (Fig. 4A), which is considered the most important wood anatomical trait influencing wood density across species (Kollmann \& Cote 1968; Zieminska et al. 2013). However, for Tocoyena formosa, the variation in wood density is not significantly related to fibers, but instead is linked to decreased vessel fraction (Fig. 4B) and increased intervessel wall thickness (Fig. 4C).

The stronger negative relationship between PFWF and sampling height in T. aurea compared to the weakly positive relationship in $T$. formosa (Fig. 3J; Estimate $=-0.07$; 0.02 , respectively) explains why the proportion of fiber wall per fiber does not impact wood density similarly in both species (Fig. 4A). By the same token, the explanation of vessel fraction in the variation of wood density of T. formosa (Fig. 4B) might be influenced by the relationship between vessel density versus sampling height (Estimate = 42.20; Fig. 3D) which is absent in T. aurea (Fig. 3D). The considerable increase in vessel density (linked to more vessel fraction and higher vessel lumen area) with sampling height is probably the driver for decreased wood density in the upper parts of the trunk of T. formosa (Fig. $3 \mathrm{I}$ ), since wood density is negatively related to vessel lumen area and positively related to the allocation of carbon (Poorter et al. 2006; Chave et al. 2009; Höltta et al. 2011).

Wood density is expected to negatively relate to water transport efficiency, since it is negatively linked to vessel lumen area (in this study for T. formosa only, Fig. 4B) and capacitance (Pratt et al. 2007; Sperry et al. 2008). In addition, wood density is defined by the presence of a stronger fiber matrix support (Jacobsen et al. 2005, 2007), as shown by T. aurea (Fig. 4A) or by the presence of vessels with thicker walls (Hacke et al. 2001; Brodribb \& Holbrook 2005) as we observe in T. formosa (Fig. 4C). These latter two mechanical characteristics are frequently cited with regards to vessel collapse prevention under increasing drought-induced negative pressures, although vessels never collapse in mature wood because embolism events always occur before the critical point of vessel collapse is reached (Hacke et al. 2001; Sperry et al.2006; Chave et al. 2009; Poorter et al. 2010). Based on this information, wood density seems to be more related to mechanical properties in T. aurea, while the link between wood density and hydraulics appears to be more obvious in T. formosa.

Along the main stem axis, higher ray fraction at the base of the trunk coincides with denser wood for both species (Fig. 3G, I). Additionally, higher ray fraction in T. formosa is correlated with higher wood density (Fig. 4D). This positive relationship between ray fraction and wood density may be surprising at first as rays consist of parenchyma cells enabling radial transport exchange between phloem and xylem (Van Bel 1990; Salleo et al. 2004; Höltta et al. 2006), as well as storage of water and minerals (Morris et al.2018). A first cause for this correlation may be related to the increased size of the lower trunks that require mechanical reinforcement (higher wood densities), but also more developed rays to transport sugars over longer radial distances. Secondly, the mechanical function of rays should not be ignored: ray fraction is found to be positively correlated to modulus of elasticity (stiffness) and radial tensile strength, both mechanical parameters that are positively linked with wood density (Mattheck \& Kubler 1995; Burgert et al. 1999; Reiterer et al. 2002; Woodrum et al. 2003; Zheng \& Martinez-Cabrera 2013; see next section). 


\section{Rays may serve different functions in both species}

The opposite trends shown by each species regarding the relationship between ray fraction and $\mathrm{K}_{\mathrm{TH}}$ (Fig. 4F), indicate that rays may have different functional roles for each species. It seems to be more related to mechanical reinforcement in Tocoyena formosa due to the positive relationship with wood density (Fig. 4D) and the negative correlation with $\mathrm{K}_{\mathrm{TH}}$ (Fig. 4F), and more related to hydraulic conductance in Tabebuia aurea due to the positive $\mathrm{K}_{\mathrm{TH}}$ link (Fig. 4F).

The opposite relationships between ray fraction and $\mathrm{K}_{\mathrm{TH}}$ for the two species is intriguing. Although this difference is difficult to explain from a functional point of view, it may be related to the marked difference in ray composition: T. aurea has homocellular rays with only procumbent cells, while $T$. formosa forms heterocellular rays with rows of upright and square cells (Dória et al. 2016). It appears that the homocellular rays in $T$. aurea, perhaps in combination with the abundant paratracheal confluent axial parenchyma form a 3D network which positively influence $\mathrm{K}_{\mathrm{TH}}$ (Fig. 4F). Contrastingly, the heterocellular rays of $T$. formosa appear to have a role in the mechanical reinforcement as shown by a positive relationship with wood density (Fig. 4D). A positive link between wood density and rays has been reported in some studies, including one analysing nearly 800 Chinese tree species (Zhang \& Martinez-Cabrera 2013). However, the relationship between mechanical strength and ray proportion is speculative, and should involve links with modulus of elasticity and modulus of rupture (Pratt et al.2007) that still remains to be assessed.

\section{Thickness of intervessel pit membrane (TPM) is linked to lignification, but shows contrasting correlations in the two species}

TPM shows relationships with two different lignification characters: a positive relationship with vessel wall thickness for Tabebuia aurea (Fig. 5A-E) and a negative relationship with the proportion of fiber wall per fiber (PFWF) for Tocoyena formosa (Fig. 6A-E). The positive link between TPM and lignification has already been emphasized via the previously observed TPM-vessel wall and proportion of lignified area in the stem correlations (Jansen et al. 2009; Li et al. 2016; Dória et al. 2018; Dória et al. in press). Moreover, TPM was found to be the functional missing link to explain why the stems of insular woody daisies are more embolism resistant compared to their herbaceous relatives (Dória et al. 2018). Although we have not measured embolism resistance in both species, it is possible that T. formosa resembles T. aurea in their embolism resistance, based on their similar intervessel pit membrane thickness (on average $311.4 \mathrm{~nm}$ and $302.5 \mathrm{~nm}$, respectively) that is hypothesized as one of the best characters to explain variation in embolism resistance amongst woody species due to the direct link with air-seeding (Lens et al. 2011; Li et al. 2016; Dória et al. 2018; Dória et al. in press). The positive link between TPM and vessel wall thickness in T. aurea can be interpreted as synergistic co-variation to cope with drought-induced embolism formation. However, the negative relationship between TPM and the proportion of fiber wall per fiber in T. formosa seems to contradict each other since a mechanically stronger fiber matrix has been linked to more - not less - embolism resistance (Jacobsen et al. 2005, 2007). 


\section{Site differences only have subtle impact on wood variation in Tocoyena formosa}

The denser wood and higher ray fraction in the individuals of Tocoyena formosa from caatinga compared to cerrado can be interpreted in different ways. Firstly, there is a difference in the size of individuals: the caatinga trees are taller $(3.40 \mathrm{~m}-5 \mathrm{~m})$ and have a thicker trunk base $(15 \mathrm{~cm}-21 \mathrm{~cm})$ compared to the cerrado ones $(1.12 \mathrm{~m}-$ $2.32 \mathrm{~m} ; 8 \mathrm{~cm}-11 \mathrm{~cm}$, respectively), which is probably related to the limited plant growth in the nutrient-poor cerrado soils with high aluminium content. As stated above, taller and wider trunks of the caatinga trees are correlated with denser wood and greater ray fraction.

In addition, our results corroborate the general trend that wood density is higher in drier environments (Chave et al. 2006; Preston et al. 2006; Onoda et al. 2010), as evidenced by the mean annual precipitation of caatinga compared to cerrado (up to $800 \mathrm{~mm}$ vs $1500 \mathrm{~mm}$, respectively). The T. formosa individuals from caatinga also show thicker vessel walls, a character that is linked with wood density in this species, and higher ray fraction. In addition to the arguments given above, increased ray fraction in $T$. formosa trees from the caatinga might be related to increased need of storage, such as starch (Evert 2006) during the harsh dry period (up to nine consecutive months per year).

\section{CONCLUSION}

In the two species studied, we find that axial sampling height along the trunk - rather than differences between sites - is a better predictor of wood trait variation; sitedependent differences were confined to only three traits (wood density, ray fraction and intervessel wall thickness) in only one species. The pattern of vessel widening does not follow a continuous course from tip to base as expected by hydraulic models. In addition, as predicted by hydraulic models, there is an increase in vessel fraction upwards to compensate for the potential decrease in conductance. Interestingly, the largest vessels are associated with the thinnest intervessel pit membranes, which synergistically reduce the hydraulic resistance.

In terms of wood density and rays, both characters show interesting co-variation with different characters along the axial trunk in the two species studied.

For Tabebuia aurea, wood density is positively related to the proportion of fiber wall per fiber suggesting a mechanical function, and rays are speculated to interact more with the hydraulic system due to the positive link with theoretical hydraulic conductivity $\left(\mathrm{K}_{\mathrm{TH}}\right)$. For Tocoyena formosa, on the other hand, wood density may counterbalance hydraulics because of its correlation with vessel fraction and intervessel wall thickness, while ray volume seems to be more related to mechanical reinforcement due to its positive relationship with wood density and negative relationship with $\mathrm{K}_{\mathrm{TH}}$. This means that - despite the fact that species have developed unique adaptational strategies to deal with environmental constraints (Dória et al.2016) - they also need to deal with species specific height-related constraints in terms of mechanicalhydraulic trade-offs. 


\section{ACKNOWLEDGEMENTS}

We thank CNPq - Conselho Nacional de Desenvolvimento Científico e Tecnológico, Brazil [Proc. No206433/2014-0)] for granting L.C. Dória, and Fundação de Amparo à Pesquisa do Estado de São Paulo, Brazil (FAPESP, Proc. 2015/14954-1) for the financial support to C.R. Marcati. We also thank Liliane C. Pereira, R. Langelaan, and W. Star for technical assistance in the laboratory. We acknowledge José Roberto Lima, Maria do Ceo Rodrigues Pessoa Barros, and Aparecido Bessa Ramon for the support during the field collection. We also thank Prof. Dr. Pieter Baas and an anonymous reviewer for their valuable comments.

\section{REFERENCES}

Aloni R, Zimmermann MH. 1983. The control of vessel size and density along the plant axis. Differentiation 24: 203-208. doi.org/10.1111/j.1432-0436.1983.tb01320.x.

Aloni R. 2015. Ecophysiological implications of vascular differentiation and plant evolution. Trees-Struct and Funct. 29: 1-16. doi.org/10.1007/s00468-014-1070-6.

Andrade-Lima D. 1981. The Caatingas dominium. Braz. J. Bot. 4: 149-163.

Anfodillo T, Petit G, Crivellaro A. 2013. Axial conduit widening in woody species: a still neglected anatomical pattern. IAWA J. 34: 352-364. doi.org/10.1163/22941932-00000030.

Baas P, Schweingruber FH. 1987. Ecological trends in the wood anatomy of trees, shrubs and climbers from Europe. IAWA Bull. n.s. 8: 245-274. doi.org/10.1163/22941932-90001053.

Borchert R, Pockman WT. 2005. Water storage capacitance and xylem tension in isolated branches of temperate and tropical trees. Tree Physiol. 25: 457-466. doi.org/10.1093/ treephys/25.4.457.

Brodribb T, Holbrook NM. 2005. Water stress deforms tracheids peripheral to the leaf vein of a tropical conifer. Plant Physiol. 173: 1139-1146. doi.org/10.1104/pp.104.058156.

Burgert I, Bernasconi A, Eckstein D. 1999. Evidence for the strength function of rays in living trees. Holz Roh Werkstoff 57: 397-399. doi.org/10.1007/s001070050367.

Burgess SO, Pittermann J, Dawson TE. 2006. Hydraulic efficiency and safety of branch xylem increases with height in Sequoia sempervirens (D.Don) crowns. Plant Cell Environ. 29: 229-239.

Carlquist S. 1975. Ecological strategies of xylem evolution. University of California Press, Berkeley.

Carlquist S. 1984. Vessel grouping in dicotyledon wood: significance and relationship to imperforate tracheary elements. Aliso 10: 505-525. doi.org/10.5642/aliso.19841004.03.

Carlquist S. 2001. Comparative wood anatomy: systematic, ecological, and evolutionary aspects of dicotyledon wood. Springer, Berlin.

Chave J, Coomes D, Jansen S, Lewis SL, Swenson NG, Zanne AE. 2009. Towards a worldwide wood economics spectrum. Ecol. Lett. 12: 351-366. doi.org/10.1111/j.1461-0248. 2009.01285.x.

Chave J, Muller-Landau HC, Baker TR, Easdale TA, Steege H ter, Webb CO. 2006. Regional and phylogenetic variation of wood density across 2456 neotropical tree species. Ecol. Appl. 16: 2356-2367. doi.org/10.1890/1051-0761(2006)016[2356:RAPVOW]2.0.CO;2.

Choat B, Cobb AR, Jansen S. 2008. Structure and function of bordered pits: new discoveries and impacts on whole-plant hydraulic function. New Phytol. 177: 608-626. doi.org/10.1111/ j.1469-8137.2007.02317.x.

Coutinho LM. 2002. O bioma do cerrado. In: Klein AL (ed.), Eugen Warming e o Cerrado Brasileiro: 77-92. UNESP, Imprensa Oficial do Estado, São Paulo.

Domec J-C, Lachenbruch B, Meinzer FC, Woodruff DR, Warren JM, McCulloh KA. 2008. Maximum height in a conifer is associated with conflicting requirements for xylem design. Proc. Natl. Acad. Sci. USA 33: 12069-12074. https://doi.org/10.1073/pnas.0710418105. 
Dória LC, Meijs C, Podadera DS, del Arco M, Smets E, Delzon S, Lens F. (in press). Embolism resistance in stems of herbaceous Brassicaceae and Asteraceae is linked with differences in woodiness and precipitation. Ann. Bot. doi: 10.1093/aob/mcy233.

Dória LC, Podadera DS, Batalha, MA, Lima, RS, Marcati CR. 2016. Do woody plants of the Caatinga show a higher degree of xeromorphism than in the Cerrado? Flora 224: 244-251. dx.doi.org/10.1016/j.flora.2016.09.002.

Dória LC, Podadera DS, del Arco M, Chauvin T, Smets E, Delzon S, Lens F. 2018. Insular woody daisies (Argyranthemum, Asteraceae) are more resistant to drought-induced hydraulic failure than their herbaceous relatives. Funct. Ecol. 32: 1467-1478. doi.org/10.1111/ 1365-2435.13085.

Evert RF. 2006. Esau's Plant Anatomy: meristems, cells, and tissues of the plant body: their structure, function, and development. Ed. 3. John Wiley \& Sons, Inc.

Fan ZX, Cao KF, Becker P. 2009. Axial and radial variations in xylem anatomy of angiosperm and conifer trees in Yunnan, China. IAWA J. 30: 1-13. doi.org/10.1163/22941932-90000198.

Fichot R, Barigah TS, Chamaillard S, LE Thiec D, Laurans F, Cochard H, Brignolas F. 2010. Common trade-offs between xylem resistance to cavitation and other physiological traits do not hold among unrelated Populus deltoides $\times$ Populus nigra hybrids. Plant Cell Environ. 33: 1553-1568. doi.org/10.1111/j.1365-3040.2010.02164.x.

Hacke UG, Sperry JS. 2001. Functional and ecological xylem anatomy. Perspect. Plant Ecol. 4: 97-115. doi.org/10.1078/1433-8319-00017.

Hacke UG, Sperry JS, Pockman WT, Davis SD, McCulloh KA. 2001. Trends in wood density and structure are linked to prevention of xylem implosion by negative pressure. Oecologia 126: 457-461. doi.org/10.1007/s004420100628.

Hacke UG, Sperry JS, Wheeler JK, Castro L. 2006. Scaling of angiosperm xylem structure with safety and efficiency. Tree Physiol. 26: 689-701. doi.org/10.1093/treephys/26.6.689.

Hacke UG, Spicer R, Schreiber SG, Plavcová L. 2017. An ecophysiological and developmental perspective on variation in vessel diameter. Plant Cell Environ. 40: 831-845. doi.org/ $10.1111 /$ pce. 12777 .

Holbrook MN. 1995. Stem water storage. In: Gardner BL (ed.), Plant stems: 151-174. Acad. Press, New York. doi.org/10.1016/B978-012276460-8/50009-6.

Höltta T, Vesala T, Perämäki M, Nikinmaa E. 2006. Refilling of embolised conduits as a consequence of 'Münch water' circulation. Funct. Plant Biol. 33: 949-959. doi.org/10.1071/ FP06108.

Höltta T, Mencuccini M, Nikinmaa E. 2011. A carbon cost-gain model explains the observed patterns of xylem safety and efficiency. Plant Cell Environ. 34: 1819-1834. doi.org/10. 1111/j.1365-3040.2011.02377.x.

IAWA Committee. 1989. IAWA List of microscopic features for hardwood identification. IAWA Bull. n.s. 10: 219-332.

IBGE [Instituto Brasileiro de Geografia e Estatística]. 2012. Manual técnico da vegetação brasileira. IBGE, Rio de Janeiro.

Iqbal M. 1995. The cambial derivatives. Schweizerbart Science Publishers, Stuttgart.

Jacobsen AL, Ewers FW, Pratt RB, Paddock WA, Davis SD. 2005. Do xylem fibers affect vessel cavitation resistance? Plant Physiol. 139: 546-556. doi/10.1104/pp.104.058404.

Jacobsen AL, Pratt RB. 2018. Going with the flow: structural determinants of vascular tissue transport efficiency and safety. Plant Cell Environ. 41: 2715-2717. doi.org/10.1111/ pce.13446.

Jacobsen AL, Pratt RB, Davis SD, Ewers FW. 2007. Cavitation resistance and seasonal hydraulics differ among three arid Californian plant communities. Plant Cell Environ. 30: 15991609. doi.org/10.1111/j.1365-3040.2007.01729.x. 
James S, Meinzer F, Goldstein G, Woodruff D, Jones T, Restom T, Mejia M, Clearwater M, Campanello P. 2003. Axial and radial water transport and internal water storage in tropical forest canopy trees. Oecologia 134: 37-45. doi.org/10.1007/s00442-002-1080-8.

Jansen S, Choat B, Pletsers A. 2009. Morphological variation of intervessel pit membranes and implications to xylem function in angiosperms. Am. J. Bot. 96: 409-419. doi.org/10.3732/ ajb.0800248.

Karnovsky MJ. 1965. A formaldehyde-glutaraldehyde fixative of high osmolality for use in electron microscopy. J. Cell Biol. 27: 137-138.

Koch GW, Sillett SC, Jennings GM, Davis SD. 2004. The limits to tree height. Nature 428: 851-854. doi.org/10.1038/nature02417.

Kollmann F, Cote WA. 1968. Principles of wood science and technology I - Solid wood. Springer Verlag.

Kord B, Kialashaki A, Kord B. 2010. The within-tree variation in wood density and shrinkage, and their relationship in Populus euramericana. Turk. J. Agric. For. 34: 121-126. doi. org/10.3906/tar-0903-14.

Lazzarin M, Crivellaro A, Williams CB, Dawson TE, Mozzi G, Anfodillo T. 2016. Tracheid and pit anatomy vary in tandem in a tall Sequoiadendron giganteum tree. IAWA J. 37: 172-185. doi.org/10.1163/22941932-20160129.

Lefcheck JS. 2015. PiecewiseSEM: Piecewise structural equation modelling in R for ecology, evolution, and systematics. Methods Ecol. Evol. 7: 573-579. doi.org/10.1111/2041210X.12512.

Lens F, Davin N, Smets E, del Arco M. 2013. Insular woodiness on the Canary Islands: a remarkable case of convergent evolution. Int. J. Plant Sci. 174: 992-1013. doi.org/10.1086/ 670259.

Lens F, Luteyn JL, Smets E, Jansen S. 2004. Ecological trends in the wood anatomy of Vaccinioideae (Ericaceae s.1.). Flora 199: 309-319. doi.org/10.1078/0367-2530-0058.

Lens F, Picon-Cochard C, Delmas CEL, Signarbieux C, Buttler A, Cochard H, Jansen S, Chauvin T, Dória LC, del Arco M, Delzon S. 2016. Herbaceous angiosperms are not more vulnerable to drought-induced embolism than angiosperm trees. Plant Physiol. 172: 661-667. doi. org/10.1104/pp.16.00829.

Lens F, Sperry J, Christman M, Choat B, Rabaey D, Jansen S. 2011. Testing hypotheses that link wood anatomy to cavitation resistance and hydraulic conductivity in the genus Acer. New Phytol. 190: 709-723. doi: 10.1111/j.1469-8137.2010.03518.x.

Li S, Lens F, Espino S, Karimi Z, Klepsch M, Schenk HJ, Schmitt M, Schuldt B, Jansen S. 2016. Intervessel pit membrane thickness as a key determinant of embolism resistance in angiosperm xylem. IAWA J. 37: 152-171. doi.org/10.1163/22941932-20160128.

Mattheck C, Kubler H. 1995. Wood - the internal optimization of trees. Springer-Verlag, Berlin.

Mattos BD, Gatto DA, Stangerlin DM, Calegari L, Melo RR, Santini EJ. 2011. Variação axial da densidade básica da madeira de três espécies de gimnospermas. Braz. J. Agric. Scienc. 6: 121-126. doi.org/10.5039/agraria.v6i1a1080.

McCulloh KA, Sperry JS. 2005. Patterns in hydraulic architecture and their implications for transport efficiency. Tree Physiol. 25: 257-267. doi.org/10.1093/treephys/25.3.257.

McDowell NG, Phillips N, Lunch C, Bond BJ, Ryan MG. 2002. An investigation of hydraulic limitation and compensation in large, old Douglas-fir trees. Tree Physiol. 22: 763-774. doi. org/10.1093/treephys/22.11.763.

Moro MF, Lughadha EN, Araújo FS, Martins FR. 2016. A phytogeographical metaanalysis of the semiarid Caatinga domain in Brazil. Bot. Rev. 82: 91-148. doi.org/10.1007/s12229016-9164-z. 
Moro MF, Lughada EN, Filer DL, Araújo FS, Martins FR. 2014. A catalogue of the vascular plants of the Caatinga Phytogeographical Domain: a synthesis of floristic and phytosociological surveys. Phytotaxa 160: 1-118. doi.org/10.11646/phytotaxa.160.1.1.

Morris H, Plavcová L, Gorai M, Klepsch MM, Kotowska M, Jochen Schenk H, Jansen S. 2018. Vessel-associated cells in angiosperm xylem: highly specialized living cells at the symplast-apoplast boundary. Am. J. Bot. 105: 151-160. doi.org/10.1002/ajb2.1030.

Moya R, Perez LD, Arce V. 2003. Wood density of Tectona grandis at two plantation spacings in Costa Rica. J. Trop. For. Prod. 9: 153-161.

Mrad A, Domec J-C, Huang C-W, Lens F, Katul G. 2018. A network model links wood anatomy to xylem tissue hydraulic behaviour and vulnerability to cavitation. Plant Cell Environ. 41: 2718-2730. doi.org/10.1111/pce.13415.

Nakagawa S, Schielzeth H. 2013. A general and simple method for obtaining R2 from generalized linear mixed-effect models. Methods Ecol. Evol. 4: 133-142. doi.org/10.1111/j. 2041-210x.2012.00261.x.

Nimer E. 1972. Climatologia da Região Nordeste do Brasil. Rev. Bras. Geogr. 34: 3-51.

O’Brien MJ, Engelbrecht BMJ, Joswig J, Pereyra G, Schuldt B, Jansen S, Kattge J, Landhausser SM, Levick SR, Preisler Y, Vaananen P, Macinnis-Ng C. 2017. A synthesis of tree functional traits related to drought induced mortality in forests across climatic zones. J. Appl. Ecol. 54: 1669-1686. doi.org/10.1111/1365-2664.12874.

Oliveira PS, Marquis RJ. 2002. The Cerrados of Brazil: ecology and natural history of a neotropical savanna. Columbia University Press, New York.

Olson ME, Rosell JA. 2013. Vessel diameter - stem diameter scaling across woody angiosperms and the ecological causes of xylem vessel diameter variation. New Phytol. 197: 1204-1213. doi.org/10.1111/nph.12097.

Olson ME, Soriano D, Rosell JA, Anfodillo T, Donoghue MJ, Edwards EJ, León-Gómez C, Dawson T, Camarero Martínez JJ, Castorena M, Echeverría A, Espinosa CI, Fajardo A, Gazol A, Isnard S, Lima RS, Marcati CR, Méndez-Alonzo R. 2018. Plant height and hydraulic vulnerability to drought and cold. Proc. Natl. Acad. Sci. USA 115: 7551-7556. doi.org/10.1073/pnas.1721728115.

Onoda Y, Richards AE, Westoby M. 2010. The relationship between stem biomechanics and wood density is modified by rainfall in 32 Australian woody plant species. New Phytol. 185: 493-501. doi.org/10.1111/j.1469-8137.2009.03088.x.

Petit G, Pfautsch S, Anfodillo T, Adams MA. 2010. The challenge of tree height in Eucalyptus regnans: when xylem tapering overcomes hydraulic resistance. New Phytol. 187: 1146-1153. doi.org/10.1111/j.1469-8137.2010.03304.x.

Pfautsch S, Aspinwall MJ, Drake JE, Chacon-Doria L, Langelaan RJA, Tissue DT, Tjoelker MG, Lens F. 2018. Traits and trade-offs in whole-tree hydraulic architecture along the vertical axis of Eucalyptus grandis. Ann. Bot. 121: 129-141. doi.org/10.1093/aob/mex137.

Pfautsch S, Keitel C, Turnbull TL, Braimbridge MJ, Wright TE, Simpson RR, O’Brien JA, Adams MA. 2011. Diurnal patterns of water use in Eucalyptus victrix indicate pronounced desiccation-rehydration cycles despite unlimited water supply. Tree Physiol. 31: 1041-1051. doi.org/10.1093/treephys/tpr082.

Pfautsch S, Renard J, Tjoelker MG, Salih A. 2015. Phloem as capacitor: radial transfer of water into xylem of tree stems occurs via symplastic transport in ray parenchyma. Plant Physiol. 167: 963-971. doi.org/10.1104/pp.114.254581.

Poorter L, Bongers L, Bongers F. 2006. Architecture of 54 moist forest tree species: traits, trade-offs, and functional groups. Ecology 87: 1289-1301. doi.org/10.1890/0012-9658 (2006)87[1289:AOMTST]2.0.CO. 
Poorter L, McDonald I, Alarcón A, Fichtler E, Licona J-C, Peña-Claros M, Sterck F, Villegas Z, Sass-Klaassen U. 2010. The importance of wood traits and hydraulic conductance for the performance and life history strategies of 42 rainforest tree species. New Phytol. 185: 481-492. doi.org/10.1111/j.1469-8137.2009.03092.x.

Pratt RB, Jacobsen AL. 2017. Conflicting demands on angiosperm xylem: tradeoffs among storage, transport and biomechanics. Plant Cell Environ. 40: 897-913. doi.org/10.1111/ pce. 12862 .

Pratt RB, Jacobsen AL, Golgotiu KA, Sperry JS, Ewers FW, Davis SD. 2007. Life history type and water stress tolerance in nine California chaparral species (Rhamnaceae). Ecol. Monogr. 77: 239-253. doi.org/10.1890/06-0780.

Preston KA, Cornwell WK, DeNoyer JL. 2006. Wood density and vessel traits as distinct correlates of ecological strategy in 51 California coast range angiosperms. New Phytol. 170: 807-818. doi.org/10.1111/j.1469-8137.2006.01712.x.

R Core Team. 2017. R: A language and environment for statistical computing. R Foundation for Statistical Computing, Vienna. http://www.R-project.org. (11 June 2018).

R Studio Team. 2016. RStudio: Integrated Development Environment for R. RStudio, Inc., Boston. http://www.rstudio.com/ (11 June 2018).

Ratter JA, Bridgewater S, Ribeiro JF. 2003. Analysis of the floristic composition of the Brazilian cerrado vegetation III: comparison of the woody vegetation of 376 areas. Edinb. J. Bot. 60: 57-109. doi.org/10.1017/S0960428603000064.

Reiterer A, Burgert I, Sinn G, Tschegg S. 2002. The radial reinforcement of the wood structure and its implication on mechanical and fracture mechanical properties - a comparison between two tree species. J. Mater. Sci. 37: 935-940. doi.org/10.1023/A:1014339612423.

Rosell JA, Olson ME, Anfodillo T. 2017. Scaling of xylem vessel diameter with plant size: causes, predictions, and outstanding questions. Curr. For. Rep. 3: 46-59. doi.org/10.1007/ s40725-017-0049-0.

Salleo S, Lo Gullo MA, Trifilo P, Nardini A. 2004. New evidence for a role of vessel-associated cells and phloem in the rapid xylem refilling of cavitated stems of Laurus nobilis L. Plant Cell Environ. 27: 1065-1076. doi.org/10.1111/j.1365-3040.2004.01211.x.

Schindelin J, Carreras A, Frise E, Kaynig V, Longair M, Pietzsch T, Preibisch S, Rueden C, Saalfeld S, Schmid B, Tinevez JY, White DJ, Hartenstein V, Eliceiri K, Tomancak P, Cardona A. 2012. Fiji - an Open Source platform for biological image analysis. Nat. Methods 28: 676-682. doi: 10.1038/nmeth.2019.

Scholz A, Klepsch M, Karimi Z, Jansen S. 2013. How to quantify conduits in wood? Front. Plant Sci. 4: 1-11. doi.org/10.3389/fpls.2013.00056.

Silva FAM, Assad ED, Evangelista BA. 2008. Caracterização climática do bioma cerrado. In: Sano SM, Almeida SP, Ribeiro JF (eds.), Cerrado: Ecologia e Flora: 71-88.Embrapa, Brasília.

Sperry JS, Hacke UG, Pittermann J. 2006. Size and function in conifer tracheids and angiosperm vessels. Am. J. Bot. 93: 1490-1500. doi.org/10.3732/ajb.93.10.1490.

Sperry JS, Meinzer FC, McCulloh KA. 2008. Safety and efficiency conflicts in hydraulic architecture: scaling from tissues to trees. Plant Cell Environ. 31: 632-645. doi.org/10.1111/j. 1365-3040.2007.01765.x.

Spicer R. 2016. Variation in angiosperm wood structure and its physiological and evolutionary significance. In: Groover A, Cronk Q (eds.), Comparative and evolutionary genomics of angiosperm trees: 19-60. Springer, Switzerland. doi.org/10.1007/7397_2016_28.

Van Bell AJE. 1990. Xylem-phloem exchange via the rays: the undervalued route of transport. J. Exp. Bot. 41: 631-644. doi.org/10.1093/jxb/41.6.631.

West GB, Brown JH, Enquist BJ. 1999. A general model for the structure and allometry of plant vascular systems. Nature 400: 664. doi.org/10.1038/23251. 
Williamson GB, Wiemann MC. 2010. Measuring wood specific gravity correctly. Am. J. Bot. 97: 519-524. doi.org/10.3732/ajb.0900243.

Woodrum CL, Ewers FW, Telewski FW. 2003. Hydraulic, biomechanical, and anatomical interactions of xylem from five species of Acer (Aceraceae). Am. J. Bot. 90: 693-699. doi. org/10.3732/ajb.90.5.693.

Zanne AE, Westoby M, Falster DS, Ackerly DD, Loarie SR, Arnold SEJ, Coomes DA. 2010. Angiosperm wood structure: global patterns in vessel anatomy and their relation to wood density and potential conductivity. Am. J. Bot. 97: 207-215. doi.org/10.3732/ajb.0900178.

Zheng J, Martínez-Cabrera HI. 2013. Wood anatomical correlates with theoretical conductivity and wood density across China: evolutionary evidence of the functional differentiation of axial and radial parenchyma. Ann. Bot. 112: 927-935. doi.org/10.1093/aob/mct153.

Zieminska K, Butler DW, Gleason SM, Wright IJ, Westoby M. 2013. Fibre wall and lumen fractions drive wood density variation across 24 Australian angiosperms. Ann. Bot. 5: 1-14. doi.org/10.1093/aobpla/plt046.

Zobel BJ, Sprague JR. 1998. Juvenile wood in forest trees. Springer, New York.

Editor: Marcelo R. Pace 


\section{Supplemental Material for: \\ Axial sampling height outperforms site as predictor of wood trait variation}

\section{Larissa C. Dória ${ }^{1, *}$, Diego S. Podadera ${ }^{2}$, Rivete S. Lima ${ }^{3}$, Frederic Lens ${ }^{1}$, and Carmen R. Marcati ${ }^{4}$}

${ }^{1}$ Naturalis Biodiversity Center, Leiden University, P.O. Box 9517, 2300 RA Leiden, The Netherlands.

2Programa de Pós-Graduação em Ecologia, UNICAMP, Campinas, São Paulo, Brazil.

${ }^{3}$ Universidade Federal da Paraíba, Centro de Ciências Exatas e da Natureza,

Departamento de Sistemática e Ecologia, 58059-900, João Pessoa, Paraíba, Brazil.

${ }^{4}$ Universidade Estadual Paulista, UNESP, Faculdade de Ciências Agronômicas, Departamento de

Ciência Florestal, Avenida Universitária, no 3780, 18.610-034, Botucatu, SP, Brazil.

*Corresponding author; email: larissa.chacondoria@naturalis.nl

\section{Content: Figure S1 and Table S1 and S2}

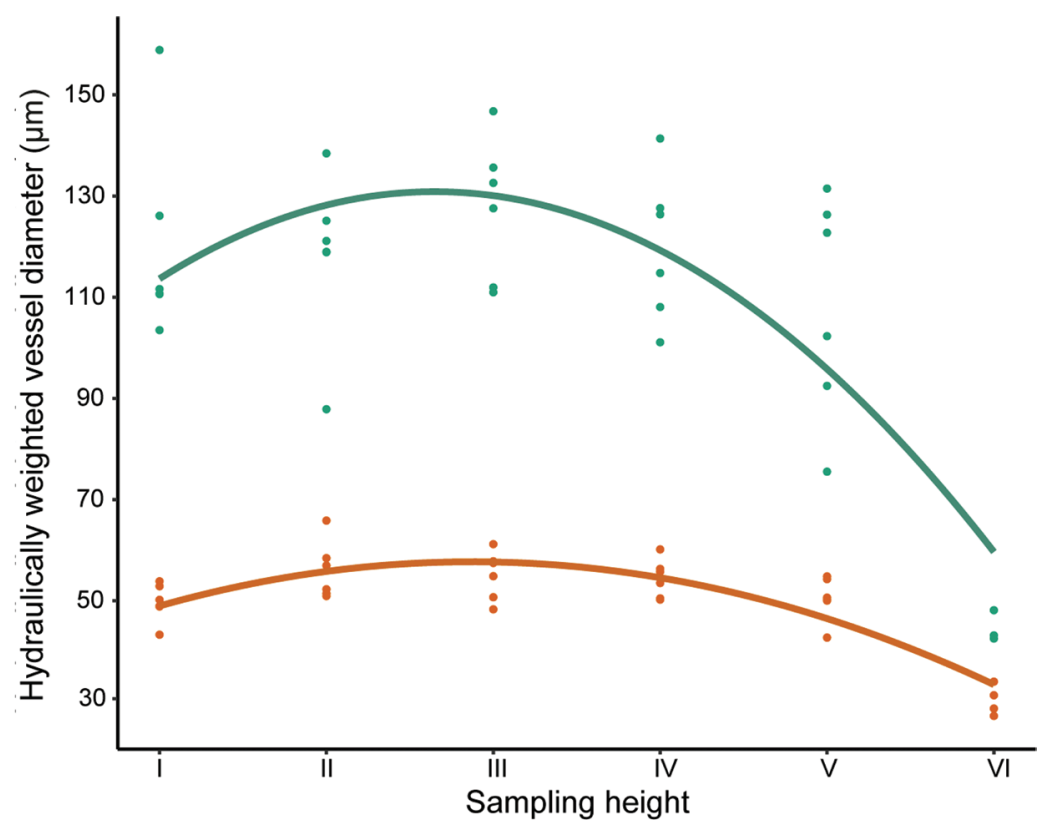

Figure S1. Relationship between hydraulically weighted vessel diameter and sampling height along the main trunk for individuals of Tabebuia aurea (green) and Tocoyena formosa (orange) from caatinga and cerrado. The "sampling height VI" refers to the measurements of the first formed vessels from sampling height $\mathrm{V}$, as a proxy for the vessel diameter closer to the stem apical meristem. The linear regression is shown for significant relationships $(P<0.05)$. 
Table S1. Relationships between wood anatomical traits, sampling height and site (caatinga and cerrado) for individuals of Tabebuia aurea and Tocoyena formosa. Regression slopes ( $\beta 1=$ slope for linear models; $\beta 2=$ slope for quadratic models $)$ and significance levels (* $P<0.05$; ** $P<0.01$; *** $P<0.001$ ) are given. The $R^{2}$ is the conditional $R^{2}$ obtained from the function $r$-squared in the package piecewiseSEM. NS = non-significant relationship; $-=$ relationship not tested.

\begin{tabular}{|c|c|c|c|c|c|c|c|c|c|c|}
\hline \multirow[b]{3}{*}{ Wood traits } & \multicolumn{5}{|c|}{ Tabebula aurea } & \multicolumn{5}{|c|}{ Tocotena formosa } \\
\hline & \multicolumn{3}{|c|}{ Sampling height } & \multicolumn{2}{|c|}{ Site } & \multicolumn{3}{|c|}{ Sampling height } & \multicolumn{2}{|c|}{ Site } \\
\hline & $R^{2}$ & $\beta 1$ & $\beta 2$ & $R^{2}$ & $\beta 1$ & $R^{2}$ & $\beta 1$ & $\beta 2$ & $R^{2}$ & $\beta 1$ \\
\hline $\begin{array}{l}\text { Hydraulically } \\
\text { weighted vessel } \\
\text { diameter }\end{array}$ & NS & NS & NS & NS & NS & 0.67 & 25.93 & $-24.51 * * *$ & NS & NS \\
\hline $\begin{array}{l}\text { Theoretical } \\
\text { hydraulic } \\
\text { conductance }\end{array}$ & NS & NS & NS & NS & NS & 0.44 & $0.040 *$ & $-0.031 * *$ & NS & NS \\
\hline Vessel fraction & 0.49 & $2.96 * *$ & - & NS & NS & 0.50 & $9.17 * * *$ & - & NS & NS \\
\hline Vessel density & NS & NS & - & NS & NS & 0.61 & $42.20 * * *$ & - & NS & NS \\
\hline Vessel grouping & 0.65 & $0.22 *$ & - & NS & NS & NS & NS & - & NS & NS \\
\hline $\begin{array}{l}\text { Thickness of } \\
\text { intervessel pit } \\
\text { membrane }\end{array}$ & NS & NS & - & - & - & NS & NS & - & - & - \\
\hline $\begin{array}{l}\text { Pit aperture } \\
\text { fraction }\end{array}$ & NS & NS & - & - & - & NS & NS & - & - & - \\
\hline Ray fraction & 0.51 & $-5.05^{*}$ & - & NS & NS & 0.58 & $-6.05^{*}$ & - & 0.46 & $-8.08 *$ \\
\hline $\begin{array}{l}\text { Axial } \\
\text { parenchyma } \\
\text { fraction }\end{array}$ & NS & NS & - & NS & NS & 0.21 & $-2.68 *$ & - & NS & NS \\
\hline Wood density & 0.55 & $0.072 * * *$ & - & NS & NS & 0.79 & $0.054 * *$ & - & 0.63 & $0.080 * *$ \\
\hline $\begin{array}{l}\text { Proportion of } \\
\text { fiber wall } \\
\text { per fiber }\end{array}$ & 0.66 & $-0.067 * *$ & - & NS & NS & 0.74 & $0.020^{*}$ & - & NS & NS \\
\hline Fiber traction & NS & NS & - & NS & NS & NS & NS & - & NS & NS \\
\hline $\begin{array}{l}\text { Thickness of } \\
\text { the intervessel } \\
\text { wall }\end{array}$ & NS & NS & - & NS & NS & NS & NS & - & 0.50 & $-1.05^{*}$ \\
\hline
\end{tabular}


Table S2. Relationships between hydraulically weighted vessel diameter, sampling height and site (caatinga and cerrado) for individuals of Tabebuia aurea and Tocoyena formosa. The above relationships include the "sampling height VI" vessel diameter measurements. Regression slopes ( $\beta 1=$ slope for linear models; $\beta 2=$ slope for quadratic models) and significance levels ( $P<0.05$; ** $P<0.01$; *** $P<0.001$ ) are given. The $R^{2}$ is the conditional $R^{2}$ obtained from the function r-squared in the package piecewiseSEM. NS $=$ non-significant relationship.

\begin{tabular}{|c|c|c|c|c|c|c|c|c|c|}
\hline \multirow[b]{3}{*}{ Wood traits } & \multicolumn{5}{|c|}{ Tabebula aurea } & \multicolumn{4}{|c|}{ Tocotena formosa } \\
\hline & \multicolumn{3}{|c|}{ Sampling height } & \multicolumn{2}{|c|}{ Site } & \multicolumn{3}{|c|}{ Sampling height } & Site \\
\hline & $R^{2}$ & $\beta 1$ & $\beta 2$ & $R^{2}$ & $\beta 1$ & $R^{2}$ & $\beta 1$ & $\beta 2$ & $R^{2}$ \\
\hline $\begin{array}{l}\text { Hydraulically } \\
\text { weighted vessel } \\
\text { diameter }\end{array}$ & 0.63 & $32.3 * * *$ & $-6.1 * * *$ & NS & NS & 0.79 & $14.49 * * *$ & $-2.52 * * *$ & NS \\
\hline
\end{tabular}

